Predicting 6-Minute

Walking Distance in

Recipients of Lung

Transplantation: Longitudinal Study of 108 Patients

Edwin van Adrichem, Gerda Reinsma, Sanne van den Berg, Wim van der Bii, Michiel Erasmus, Wim Krijnen, Pieter Dijkstra, Cees van der Schans

\section{Klinische vraag}

Wat is het beloop van het functionele inspanningsvermogen rondom longtransplantatie gemeten door middel van de 6 minuten loopafstand en welke factoren beïnvloeden dit?

\section{Conclusie van de auteurs}

Fysiotherapeutische interventies voor en na longtransplantatie moeten zich richten op het verbeteren van de quadriceps-kracht om het functionele uithoudingsvermogen te verhogen. Echter, de interventies zullen uitgebreider moeten zijn voor optimale effectiviteit. Het verloop van het herstel in 6 minuten loopafstand laat zien dat extra aandacht nodig is in de periode tussen 6 en 12 maanden na transplantatie.

\section{Onderzoeksopzet}

Longitudinaal historisch cohortonderzoek.

\section{Onderzoekslocatie}

Poliklinische en klinische setting Universitair Medisch Centrum.

\section{SAMENVATTING}

Inspanningscapaciteit, spierfunctie en fysiek activiteitenniveau blijven gereduceerd in ontvangers van een longtransplantatie, dit ondanks een goede functie van het getransplanteerde orgaan. Factoren die geassocieerd zijn met dit tekort aan functioneel inspanningsvermogen, zijn niet eerder longitudinaal onderzocht. De gegevens van 108 mensen die een longtransplantatie hebben ondergaan, zijn retrospectief geanalyseerd op beloop in 6 minuten loopafstand en op voorspellende factoren voor deze loopafstand tijdens screening, ontslag na transplantatie en 6 en 12 maanden na transplantatie. Een linear mixed model-analyse en een logistische regressie zijn uitgevoerd met gebruik van patiëntkarakteristieken, diagnose, wachtlijstduur, duur van de ziekenhuisopname, mate van rejectie, longfunctie en perifere spierkracht. Factoren die 6 minuten loopafstand voorspelden waren: meetmoment, diagnose, geslacht, quadricepsen knijpkracht, forced expiratory volume in 1 seconde (FEV1, \% voorspeld) en de duur van de ziekenhuisopname. Na transplantatie nam de 6 minuten loopafstand aanzienlijk toe. Deze initiële toename werd echter niet doorgezet tussen 6 en 12 maanden. Een jaar na transplantatie haalde $58 \%$ van de patiënten niet de drempelwaarde voor 'normaal' functioneren van de voorspelde 6 minuten loopafstand. De logistische regressie liet zien dat ontslagwaarden voor FEV1 en quadriceps- of knijpkracht voorspellers waren voor het behalen van deze drempelwaarde. Een beperking van de studie was het gebrek aan kennis over het verloop van de ziekte tijdens de wachtlijstperiode en het type en frequentie van fysiotherapie na transplantatie. De verwachting is dat het zinvol is om naast quadricepstraining ook cardiopulmonale training aan te bieden en aandacht te schenken aan het verhogen van het dagelijks activiteitenniveau en overige leefstijlaspecten.

Edwin van Adrichem, promovendus en fysiotherapeut, werkzaam bij het lectoraat Healthy Ageing, Allied Health Care and Nursing, Hanzehogeschool Groningen en de afdeling Revalidatiegeneeskunde, Universitair Medisch Centrum Groningen.

Summarized from Phys Ther [May 2015] CC American Physical Therapy Association. To read the full-text article: http://ptjournal. apta.org/content/95/5/720.full.pdf+html

\section{Incorporating Self-}

Management in Prosthetic Rehabilitation: Case Report of an Integrated Knowledgeto-Action Process.

Sacha van Twillert, Klaas Postema, Jan Geertzen, Ant Lettinga

\section{Klinische vraag}

Welke (onderzoeks)activiteiten zijn nodig om wetenschappelijke kennis over zelfmanagementeducatie en taak- en contextspecifieke training te integreren in de amputatierevalidatie om patiënten te helpen het resultaat ook thuis te behouden?

\section{Conclusie van de auteurs}

Wie lokale revalidatiepraktijken met inzet van wetenschappelijke kennis wil verbeteren, doet er goed aan de verschillende soorten kennis (wetenschappelijke, therapeutische, patiënten en contextuele kennis) op een gelijkwaardige manier te waarderen en te integreren. Het gaat om een multidimensioneel leerproces, waarin innovatieonderzoekers en betrokken therapeuten, patiënten en managers in een interactief en cyclisch proces samenwerken.

\section{Onderzoeksopzet}

Participatief actieonderzoek, conceptuele analyses en mixed-methods-methodologie leverden input voor dit geïntegreerde Knowledge-To-Action (KTA)-onderzoek.

\section{Onderzoekslocatie}

Universitair Medisch Centrum Groningen Centrum voor Revalidatie.

\section{SAMENVATIING}

Het amputatierevalidatieteam definieerde het klinische probleem in de bezorgdheid dat veel patiënten het geleerde in het revalidatiecentrum thuis niet konden behouden. De KTA-expert signaleerde in zowel de wetenschappelijke literatuur over prothesetraining als in de lokale werkdocumenten een focus op biomedische en biomechanische theorievorming en onderbelichting van leertheorieën. Aansluiting werd gezocht bij zelfmanagementprincipes uit de revalidatie voor chronische zieken en bij taaken contextspecifieke trainingsprincipes uit de neurologische en ouderenrevalidatie. Beide trainingen worden als evidence-based praktijken gekwalificeerd. Focusgroepinterviews met patiënten en therapeuten leverden amputatiespecifieke kennis voor invulling van de behandelprincipes en technieken van zelfmanagementeducatie en taak- en contextspecifieke training. Werkstations werden ingericht en instructies en feedback gespecificeerd om therapeuten te leren de actieve participatie en het probleemoplossend vermogen van patiënten te stimuleren. Therapeuten, managers en patiëntenverenigingen evalueerden het vertaalproces en brachten mogelijke implementatieproblemen in kaart. Verschillende activiteiten werden ondernomen om deze te ondervangen. Zo kregen therapeuten scholing om ingeslepen routines los te laten en meer oplossingsgericht te trainen. De leerervaringen van therapeuten en patiënten tijdens de proefimplementatie hielpen de training te verfijnen. Eindresultaat: gedeeld eigenaarschap van de circuittraining, ${ }^{2}$ nu vast onderdeel van de lokale revalidatie voor patiënten met een beenamputatie.

Drs. Sacha van Twillert, UMCG - Centrum voor Revalidatie, Groningen.

Summarized from Phys Ther [April. 2015] (C) American Physical Therapy Association. To read the full-text article: http://ptjournal.apta.org/content/95/4/640.full. pdf+html.

Straus SE, Tetroe J, Graham ID, eds. Knowledge Translation in Health Care: Moving From Evidence to Practice. 2nd ed. Chichester, United Kingdom: John Wiley \& Sons Ltd; 2013

2 Zelfmanagement in beweging; regietraining en circuittraining voor de revalidatie na een beenamputatie. Drs Sacha van Twillert, UMCG-Centrum voor Revalidatie, 2012. ISBN: 9789074768481. 